\title{
Semmelweis császármetszése Pesten 1857-ben
}

\author{
A Nemzetközi Semmelweis-emlékév tiszteletére
}

\author{
Szabó András dr.
}

Semmelweis Ignác Fülöp (1818-1865) munkásságának méltatása során általában a gyermekágyi lázzal kapcsolatos korszakalkotó felfedezése kerül előtérbe, így kevés szó esik mütéti tevékenységéről, amelynek jelentőségét az 1857. március 19-én végzett császármetszése és az 1863-ban történt első magyarországi ovariotomia adja meg. Korbuly György (1903-1981), a magyar szülészet fáradhatatlan kutatója írta: „Rámutattunk, Semmelweis klinikájának megmaradt kimutatásait áttanulmányozva, hogy vele friss, addig ismeretlen operativ szellem honosodott meg a pesti egyetem szülészeti klinikáján” [1].

\section{A mütét helyszíne}

Semmelweis Ignácot 1855-ben nevezték ki az akkori nevén Pesti Császári és Királyi Egyetem Elméleti és Gyakorlati Szülészeti Tanszék élére (1. ábra). A tanszék 1812-es megalapítását követően Frankenburg Jakab (1781-1814), Stabli Ignác (1787-1849), Birly Ede (1787-1854) és Walla Ferenc (1813-1869) után ötödikként töltötte be a tanszékvezetői posztot. A klinika ekkor Pesten a Hatvani (ma Kossuth Lajos) utca és az Újvilág (ma Semmelweis) utca sarkán lévő kétemeletes épületben, egy volt jezsuita kolostorban múködött. A lehangoló körülményeket Kézmárszky Tivadar (18421902), Diescher János (1813-1883) után Semmelweis tanszéki utóda így jellemezte: „A szülészeti klinikum akkoriban az Újvilág utcai orvoskari épületnek második emeletén volt elhelyezve, s egy szülö- és négy gyermekágyi szobából állott, összesen 26 ággyal. ... Az intézet ablakainak jó része szük udvarra nyilt, melyben a szemétgödrön kivül a halottas kamra volt, s az intézet alatt fekvó földszintet a boncolási terem, elsó emeletét ellenben a vegytani intézet foglalta el, melynek kéményei a klinikumnak falait szinte türbetetlen módon áthevitették" [2]. Ebben az épületben volt még Balassa János (1814-1868), a kor egyik legnagyobb sebészének 13 ágyas „klinikája”. Itt történt Semmelweis császármetszése is, mint tanársegédje, Fleischer Józsefírta: „Legalkalmasabb helyiségül e célra a sebészi hallgatóterem lön kiszemelve” [3].

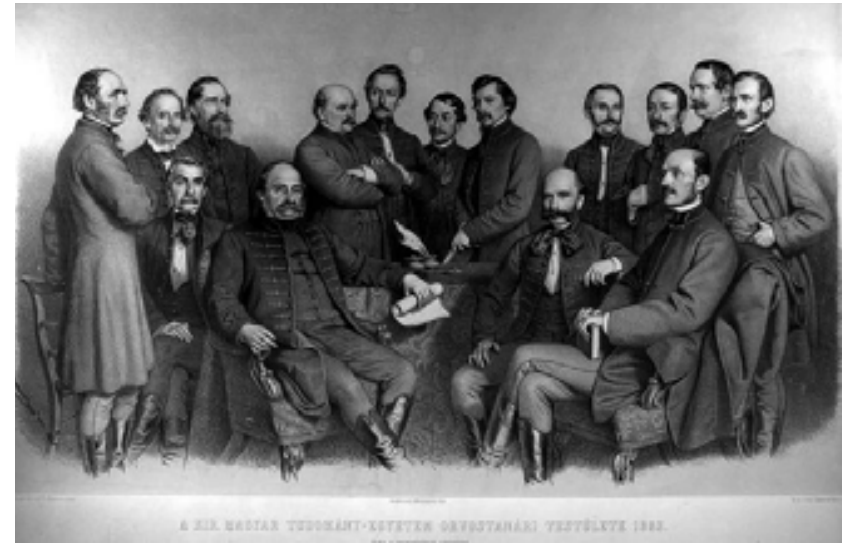

1. ábra $\quad$ A Budapesti Királyi Magyar Tudományegyetem orvostanári kara 1863-ban. Állnak (balról): Diescher János, Wágner János, Arányi Lajos, Semmelweis Ignác, Lippay Gáspár, Lenhossék József, Jendrassik Jenő, Nedelkó Döme, Linzbauer Ferenc, Wachtel Dávid, Stockinger Tamás. Ülnek: Zlamál Vilmos, Sauer Ignác, Rupp N. János és Balassa János

\section{A mütét asszisztense}

Semmelweis első asszisztensének professzortársát, Balassa Jánost (1814-1868) kérte fel, „aki az első és legkényesebb segédletet szíves volt elvállalni a mütét egész tartama alatt, s a mütevövel szemben állt” [3]. Balassa 1843-ban, 28 éves korában kapta kinevezését a pesti egyetem sebészeti tanszékére. Bécsben szerzett orvosi, sebésztudori és szülészmesteri diplomája volt, szülészetet is előadott. Az ő segédkezése mellett végezte Semmelweis 1863. június 22-én az első magyarországi ovariotomiát. (Balassa volt Erzsébet királyné szülészorvosa a budai várban 1868. április 22-én Valéria föhercegnő születésekor. A királyné nevének kezdőbetúivel díszített gyémántgyưrúvel mondott köszönetet orvosának.)

\section{A szülőnő}

P. Teréz 23 éves hajadon, szegény budai varrónő, angolkór miatt súlyosan deformált medencéje és végtagjai miatt hatéves koráig járni sem tudott. Terhességét titkolta, 
környezete hasvízkórnak gondolta, és különböző házi szerekkel kezelte. 1857. március 17-én éjjel kezdődtek a szülőfájásai, majd elfolyt a magzatvize. 18-án hajnalban bábát hívtak, aki délután orvosi segítséget kért. Az orvos többször meglátogatta, majd miután felismerte a helyzet reménytelenségét, 19-én hajnalban a szülészeti kórodába utalta. Az itt történteket Fleischer József leírásából ismerjük [3]. Megállapítást nyert, hogy egyszerü fartartásban elhelyezkedő halott magzat mellett az angolkór miatt kialakult nagyfokú medenceszúkület hüvelyi szülést nem tesz lehetővé, „a császármetszés épenesen (absolute) javaltaték”, ennek ellenére reggel nyolc órakor lábra fordítást és a magzat extrakcióját kísérelték meg, de a szúk viszonyok miatt még a kéz felvezetése is lehetetlen volt.

\section{A mütét}

„Dél elötti 10 órakor az orvosi tanácskozmányra meghívott orvosi kar megjelent. Semmelweis tanár röviden, velösen elmondván a történetet, véleményében az átalán és szükségképen javalott császármetszés mellett nyilatkozott, mely jelen esetben csak az anya lehetó megmentése miatt javaltatik. Erre több szakférfi által a nö megvizsgáltatván, a fenemlitett véleményben mindnyájan megegyeztek. ...

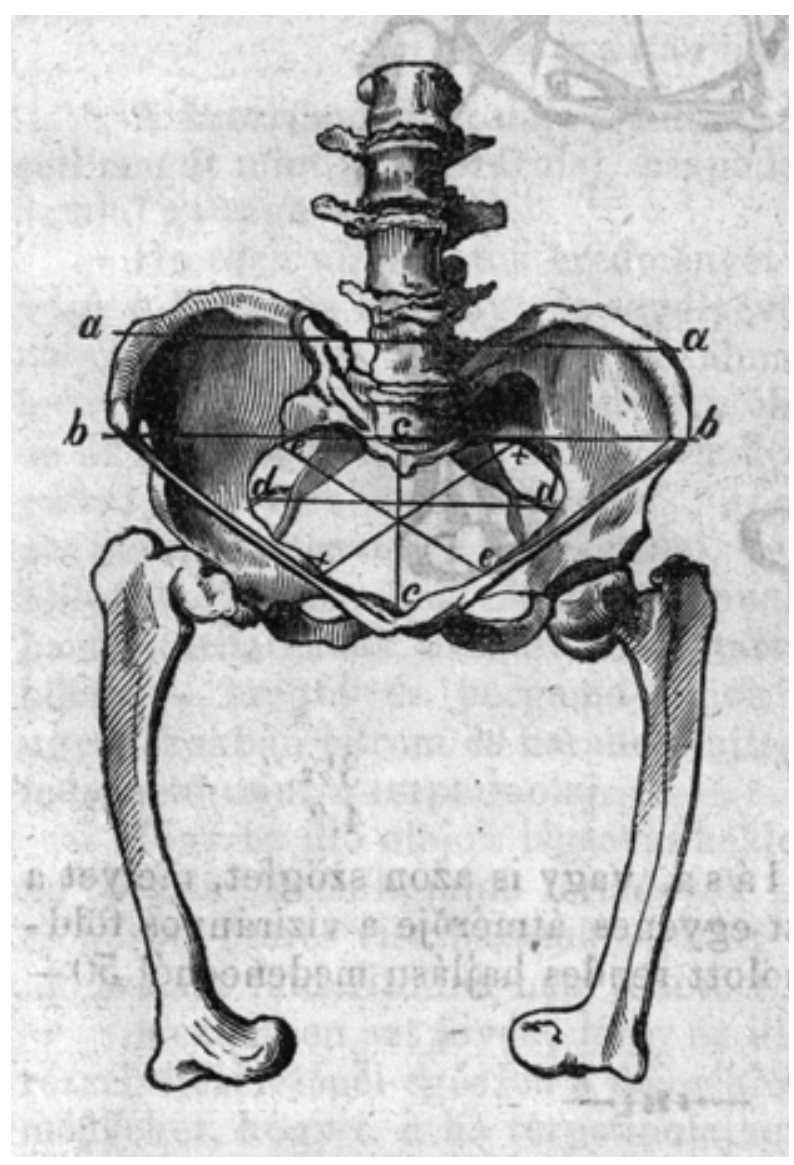

2. ábra P. Teréz preparált medencéjének rajza Fleischer közleményében, 1857
A mütét végrehajtására déli 12 óra tüzetett ki. A kijelölt idöre az egyetemi tanár urak közöl többen, tanársegédek, számos vendég és hallgató gyült egybe. Semmelweis tanár a mütét terve világos elemzése után a szenvedöt a mütöasztalra hozatta, s a feladat megoldásához fogott. ... egy a beteg fejénél álló segéd által a hangyhalvannyali (kloroform) kábitás eszközöltetett.” A mútét a szokásos módon folyt le, a has megnyitása a linea alba mentén, az uterus megnyitása hosszanti metszéssel történt. A halott magzat és a placenta eltávolítása után a vérzést jeges vízzel csillapították. Miután az uterus összehúzódott és a vérzés megszûnt, a hasfalat csapos varrattal (Zapfennath) egyesítették. Méhvarrat a kor szokásának megfelelően nem történt. „A szenvedöt varrat-alkalmazás közben ájulások környékezék, mire jó vörös bor nyújtaték neki kanalankint. Kötés után bideg borogatások alkalmaztattak hasára, olykor csuklás jelentkezett, mely ellen sósavas szunynyadék nyújtaték neki. ...Másnap (20-án) reggel a beteg arca sápadt, igen beesett, magaviselete nyugodt és türelmes ... Déltájban érverést tapintani többé nem lehetett, sáltalános gyöngeség minden tüneményei között déli 12 órakor kimult. ... Boncoltatása elrendeltetvén; erre Arányi tanár. kéretett föl, ki a boncolást 21-kén reggeli 9 órakor megtevé; ... A medence vázittatván a helybeli szülkóroda gyüjteményében öriztetik”[3]. A halál okát peritonitisben jelölte meg.

\section{A mütét dokumentációja}

Ismert, hogy Semmelweis sem közlemények írását, sem előadások tartását nem kedvelte. Ez esetben azonban kivételt tett, és az esetet ismertette a Magyar Királyi Orvosegyesület ülésén 1857-ben, mint az Kovács Sebestyén Endre (1814-1878) egyesületi titkár 1857 októberében tartott éves beszámolójából kitűnik: „A szülészet Prof. Semmelweis által nyerte személyesitójét, ki az angolkóros nönél tett császármetszést, a petefészek vizdaggal párosult szülést, szakismeretekkel szerkesztett, mind kórhatározóilag, mind gyakorlati kivitelben egyaránt fontos eseteknek elóadásával szakképzettségének tanúságát adá.” [1]. Az írásos beszámolót azonban már tanársegédje, Fleischer József(1829-1877) tette közzé az Orvosi Hetilap 1857es első évfolyamában [3] (2. ábra).

\section{Semmelweis korábbi császármetszései}

Nem ez volt Semmelweis első császármetszése. Franz Hektor Arneth (1818-1907) Die geburtshilfliche Praxis című könyvéből ismert, hogy Semmelweis bécsi múködése alatt három császármetszést végzett, igaz, azokat post mortem. Arneth Semmelweis bécsi kollégája és barátja volt az 1847-1849-es években. Adatai szerint a bécsi szülőklinikán az 1789-1849 közötti hatvan évben öt császármetszés történ élő szülőnőn, mind az öt asszony meghalt, a gyermekek azonban életben maradtak. Maga Arneth négy post mortem mútétet végzett, egy gyermek maradt életben. Ezzel kapcsolatban egy lábjegyzetben 
írta a következőket: „Az I. Klinika korábbi asszisztense, Dr. Semmelweis olyan szerencsés volt, hogy már három gyermeket mentett meg császármetszéssel az anya halála után. Az egyik anya tuberkulózisban, a másik eklampsiában, a harmadik nyak alatti szövetek gennyedésében szenvedett" (Dass der frühere Assistent an der I. Klinik, Dr. Semmelweis, das Glück gehabt hat, schon 3 Kinder durch den Kaiserschnitt, nach dem Tode der Mutter, zu retten. Eine dieser Mütter hatte an Tuberculose, eine an Eclampsie und eine an Vereitung des Halszellgewebes gelitten) [4]. Semmelweis maga említi fő múvében, a Die Aetiologie-ban: „Az elsö császármetszést in mortua egy terhessége alatt febris puerperalisban meghalt asszonyon végeztem." A mütét Bécsben történt, de az évszámot nem említi (Den ersten Kaiserschnitt in mortua habe ich an einem in der Schwangerschaft an Puerperalfieber verstorbenen Individuum gemacht) [5]. Semmelweis viszonylag rövid pályafutása alatt tehát öt császármetszést végzett, négyet post mortem és egyet élő asszonyon. Összehasonlításul megemlíthetjük, hogy például egy generációval később Mann Jakab (1848-1923), a szegedi bábaképző megalapítója és igazgatója, aki 1906-ban nemességet, 1911-ben udvari tanácsosi címet kapott, 35 éves múködése alatt egy - sikeres - császármetszést végzett 1913-ban.

\section{A császármetszés kezdetei Magyarországon}

Történelmi kontextusba helyezve, Semmelweis császármetszése az ötödik volt a történelmi Magyarország területén, és a második élőn végzett mütét [6].

Az elsőt Knie József Márton városi fóorvos (született: 1758 ) végezte 1785-ben Szegeden post mortem. Második a Borsodi Terézia nevezetes váci múmiáján felismert mütét 1794-ben. A harmadik Pongrácz Mihály (18051879 ) mútétje 1839-ben valószínúleg Losoncon, amelyet az első élőn végzett császármetszésként tartunk számon $[7,8]$. A negyedik 1849. január 4-én történt egy kizárt sérv miatt meghalt terhesen a pesti klinikán Birly Ede tanársága idején. Ezt Korbulytól tudjuk, aki átnézte a klinika 1831-től meglévő dokumentációját, és ez volt az intézetben az első császármetszés. Semmelweis mütétje a klinika 1857. évi jegyzőkönyvében a 353 szám alatt található [9].

Semmelweis mütétjének jelentőségére utal, hogy a következő császármetszésre csak hét év múlva került sor,
Riméli Sándor végezte 1864-ben a budapesti Szt. Rókus Kórházban post mortem, a gyermek három hétig élt. Ezt még négy sikertelen mütét követte, míg 1890-ben Tauffer Vilmosnak (1851-1934) köszönhetően elsőként maradt életben anya és gyermeke Magyarországon császármetszés után.

\section{Irodalom}

[1] Korbuly, Gy.: Semmelweis and the Hungarian Royal Medical Company. [Semmelweis és a Budapesti Királyi Orvosegyesület.] Budapesti Orvosi Ujság, 1938, 36, 277-279. [Hungarian]

[2] Kézmárszky, T.: First Department of Obstetrics and Gynecology. In: Hőgyes, E. (ed.): Memory Book of the Past and Presence of the Medical Faculty of the Royal Hungarian University of Budapest. [Első Szülészeti és Nőbeteg Klinika. In: Hőgyes, E. (szerk.): Emlékkönyv a Budapesti Királyi Magyar Tudomány Egyetem Orvosi Karának Múltjáról és Jelenéről.] Magyar Orvosi Könyvkiadó Társulat, Budapest, 1896. [Hungarian]

[3] Fleischer, J.: Caesarean section performed on living subject suffering from rachitic narrow pelvis. [Császármetszés élőnél angolkóros (rhachiticus) medenceszúkület miatt.] Orv. Hetil., 1857, 1(8) 120-121., (9) 134-136., (10) 153-155. [Hungarian]

[4] Arneth, F. H.: Die Geburtshilfliche Praxis. W. Braumüller, Wien, 1851, 112-113. [German]

[5] Semmelweis, I. Ph.: Die Aetiologie, der Begriff und die Prophylaxis des Kindbettfiebers. C. A. Hartleben, Pest, Wien und Leipzig, 1861. [German]

[6] Szabó, A.: The first authentic caesarean sections. [Az első hiteles császármetszések.] Magy. Nőorv. L., 2011, 74(1), 42-48. [Hungarian]

[7] Kiss, L.: From the history of medicine in Upper Hungary. [Az orvostudomány felvidéki történetéből.] Magyar Tudománytörténeti Intézet, Piliscsaba, 2010. [Hungarian]

[8] Varjassy, P.: The history of caesarean section in Hungary to the end of 19th century. [A császármetszés története Magyarországon a XIX. század végéig.] Orv. Hetil., 2002, 143(44), 24932499. [Hungarian]

[9] Korbuly Gy.: The beginning of Hungarian obstetrics. [A magyar szülészet bölcső́kora.] Orvosképzés, Special issue, 1936, 242. [Hungarian] 